\title{
Optimasi Sediaan Pelembab Ekstrak Kering Kulit Buah Manggis (Garcinia mangostana L.) dengan Kombinasi Asam Stearat dan Trietanolamin sebagai Emulgator
}

\author{
Nur Chomariyah $^{\left(a^{*}\right.}$, Farida Lanawati Darsono ${ }^{(a)}$, Sumi Wijaya ${ }^{(a)}$ \\ (a) Fakultas Farmasi Universitas Katolik Widya Mandala, Surabaya
}

\begin{abstract}
Buah manggis merupakan salah satu tanaman tropis yang memiliki banyak khasiat untuk sediaan kosmetika. Kandungan zat aktif berkhasiat pada kulit buah manggis yaitu alfa mangosteen. Selain berefek sebagai antioksidan, alfa mangosteen juga memiliki efek sebagai pelembab kulit yang dapat memberikan perlindungan akibat dari kondisi kulit kering. Tujuan penelitian ini untuk mengetahui pengaruh kombinasi emulgator asam stearat dan trietanolamin terhadap sifat fisik dan efektivitas serta untuk mendapatkan formula optimum. Formulasi dibagi menjadi 4 kelompok, formula A terdiri dari asam stearat $10 \%$ dan trietanolamin $0,1 \%$, formula B terdiri dari asam stearat $16 \%$ dan trietanolamin $0,1 \%$, formula $C$ terdiri dari asam stearat $10 \%$ dan trietanolamin $0,5 \%$ dan formula $D$ terdiri dari asam stearat $16 \%$ dan trietanolamin $0,5 \%$ sesuai dengan metode optimasi factorial design. Optimasi formula dengan menggunakan Design Expert. Hasil uji mutu fisik dan efektivitas sediaan dianalisis menggunakan uji one way ANOVA (post-hoc Tukey) dengan taraf kepercayaan 95\%. Hasil penelitian menunjukkan asam stearat berpengaruh menurunkan respon terhadap daya sebar dan efektivitas sediaan, serta meningkatkan $\mathrm{pH}$, viskositas, daya lekat dan daya tercucikan air. Trietanolamin memberikan respon terhadap penurunan daya sebar dan efektivitas serta peningkatan terhadap $\mathrm{pH}$, viskositas, daya lekat, daya tercucikan air. Interaksi keduanya dapat meningkatkan $\mathrm{pH}$, viskositas, dan efektivitas sediaan serta menurunkan daya sebar, daya lekat, dan daya tercucikan air pada sediaan pelembab krim ekstrak kulit buah manggis. Formula optimum sediaan krim pelembab ekstrak kering kulit buah manggis yang didapatkan dengan program design expert adalah kombinasi asam stearat $14,02 \%$ dan trietanolamin $0,41 \%$ sebagai emulgator anionik.
\end{abstract}

Kata kunci: Alfa-mangosteen, Asam stearat, Optimasi, Sediaan Krim Pelembab, Trietanolamin.

\section{The Optimization of Moisturizing Cream Containing the Dry Extract of Mangosteen (Garcinia mangostana L.) Pericarp Using a Combination of Stearic Acid and Trietanolamine as an Emulsifying Agent}

\begin{abstract}
Mangosteen is a plant which has a high antioxidant activity. The mangosteen pericarp contains antioxidant compound alpha mangosteen. Beside as an antioxidant, alpha-mangosteen has the potential as skin moisturizer, which gives protection for dry skin condition. The purpose of this research was to know the influence a combination stearic acid and trietanolamin on the physical characteristics and effectiveness. As the results of this researchs optimum formula was obtained using factorial design expert. The formula divided into 4 groups, formula A $10 \%$ of stearic acid and $0.1 \%$ trietanolamine, formula B was $16 \%$ of staric acid and $0.1 \%$ trietanolamine, formula C $10 \%$ of stearic acid and $0.5 \%$ trietanolamine and formula D $16 \%$ of stearic acid and $0.5 \%$ trietanolamine. Effectiveness and physical quality results were analyzed using one way anova and post hoc tukey with the level of confidence 95\%. The results showed that stearic acid as an emulsifying agent have significant effect on the decrease of spreadibility, effectiveness and an increase in $\mathrm{pH}$, viscosity, stickiness and ease for removal. Triethanolamin as an emulsifying agent had significant effect on them decrease of spreadibility, effectiveness and an increase in pH, viscosity, stickiness, and ease for removal. Interaction of both agents had signifficant effect to increase $\mathrm{pH}$, viscosity, and effectiveness and a decrease in spreadibility, stickiness, and ease to removal of moisturizing cream containing the extract mangosteen pericarp. Optimum formula of moisturizing cream dry extract of mangosteen pericarp was obtained, a combination of $14.02 \%$ stearic acid and $0.41 \%$ trietanolamine as an anionic emulsifying agent.
\end{abstract}

Keywords: Alpha-mangosteen, Stearic Acid, Optimation, Moisturizer Cream, Trietanolamine

${ }^{*}$ Corresponding author: Fakultas Farmasi Universitas Katolik Widya Mandala Surabaya, Jl. Raya Kalisari Selatan No.1 Surabaya, e-mail: nur.chomariyah93@gmail.com 


\section{PENDAHULUAN}

Kulit merupakan salah satu organ tubuh yang sangat penting berfungsi sebagai barrier protektif terhadap pencegahan kehilangan air dan elektrolit (Pillai, Cornel dan Oresajo, 2010). Berbagai faktor internal dan eksternal seperti udara kering, iklim, temperatur, paparan sinar matahari, usia lanjut, penyakit kulit maupun penyakit dalam tubuh dan faktor lainnya dapat menyebabkan kulit menjadi kering akibat dari penguapan air pada kulit yang cepat (Wasitaatmadja, 1997). Penguapan yang berlebihan tersebut menyebabkan kulit menjadi kering dan kandungan air dalam stratum korneum kurang dari 10\% (Rawlings, Canestrari and Doblowski, 2004). Sehingga diperlukan perlindungan tambahan dari luar untuk mempertahankan kelembaban kulit yaitu sediaan pelembab.Penggunaan antioksidan dalam sediaan pelembab memiliki nilai lebih karena memiliki perlindungan yang lebih besar terhadap pengaruh lingkungan (matahari, polusi, angin dan temperatur) pada kulit, sehingga menghambat penuaan dan kerusakan kulit (Mishra and Chattopadhayay, 2010).

Salah satu bahan alam yang dapat digunakan sebagai sediaan pelembab yaitu kulit buah manggis. Manfaat ekstrak kulit buah manggis dalam bidang kosmetik secara in vivo telah diteliti manfaatnya dalam meningkatkan kelembaban kulit (Tilaar et al., 2009; Thornfeldt and Bourne, 2010; Wasitaatmadja, 2011). Kandungan kulit buah manggis yang dimanfaatkan sebagai senyawa antioksidan adalah alfa mangosteen yang merupakan senyawa polyphenolic (Mahabusarkam, Iriyachitra and Taylor, 1987; Nilar et al., 2005). Sifat umum sediaan krim adalah mampu melekat pada permukaan tempat pemakaian dalam waktu yang cukup lama sebelum sediaan ini dicuci atau dihilangkan. Krim dapat memberikan efek mengkilap, berminyak, melembabkan dan mudah tersebar merata, mudah berpenetrasi pada kulit, mudah/sulit diusap, mudah/sulit dicuci air (Anwar, 2012).

Formula sediaan pelembab memiliki komponen emulgator yang terdiri dari kombinasi asam stearat dan trietanolamin. Asam stearat akan membentuk sediaan krim yang stabil dan memiliki mutu fisik yang baik jika dikombinasikan dengan trietanolamin pada konsentrasi yang tepat. Berdasarkan hal tersebut, kedua komponen tersebut akan dioptimasi dengan metode factorial design. Faktor yang digunakan adalah kombinasi asam stearat (-) 10\% dan (+) 16\% dengan trietanolamin (-) 0,1\% dan (+) 0,5\%. Respon yang akan dilihat adalah respon $\mathrm{pH}$, viskositas, daya sebar, daya lekat, daya tercucikan air serta efektivitas sediaan. Optimasi yang dilakukan menggunakan program software design expert ver. 10.0. Evaluasi juga dilakukan analisa statistik dengan uji one way ANOVA (post-hoc Tukey's).

Tujuan dari penelitian ini adalah untuk mengetahui kombinasi asam stearat dan trietanolamin sebagai emulgator terhadap mutu fisik dan efektivitasnya serta interaksi antar keduanya dan untuk mendapatkan formula optimum sediaan krim pelembab ekstrak kering kulit buah manggis (Garcinia mangostana L.)

\section{METODE PENELITIAN Bahan}

Bahan-bahan yang digunakan dalam penelitian ini adalah ekstrak kering kulit buah manggis (PT. Natura Laboratoria Prima), asam stearat (dari PT. Brataco, Bogor), gliserin (Loba Chemie PVT, LTD), gliseril monostearat (Croda Pto Ltd, Singapore), metil paraben (Amresco, LLC), trietanolamin (Loba Chemie PVT, LTD), carbomer (Making Cosmetics, Singapore), propilen glikol (Dow Chemical Pasific, Singapore) aquadest (Loba Chemie PVT, LTD), etanol 96\% (Mailinckrodt Baker Inc, Philipsburg)), metanol (Mailinckrodt Baker Inc, Philipsburg), heksana (Mailinckrodt Baker Inc, Philipsburg), etil asetat (Mailinckrodt Baker Inc, Philipsburg), kloroform (Mailinckrodt Baker Inc, Philipsburg).

\section{Alat}

Alat-alat yang digunakan dalam penelitian ini adalah timbangan analitik (Sartorius BP 110S, Germany), waterbath, pH meter (Cybercam, Singapore), chamber (CAMAG, Swizerland), silika gel (Merck, Germany), vortex, viskometer Brookfield (Mecomb, Singapore), kertas perkamen, kertas saring, gelas ukur dan alat-alat gelas lainnya.

\section{Standarisasi Ekstrak}

Ekstrak yang diperoleh dari PT. Natura Laboratoria Primadistandarisasi spesifik dan non spesifik untuk menjamin kestabilan mutu bahan sehingga dapat digunakan dalam proses formulasi. Standarisasi non spesifik terdiri dari pengujian kadar air, pengujian kadar abu total, kadar abu larut air dan kadar abu tidak larut asam (Ditjen POM, 2000). Standarisasi spesifik terdiri dari pemeriksaan organoleptis, pengujian $\mathrm{pH}$, susut, pengeringan, kadar sari larut air, kadar sari larut etanol.

\section{Penentuan Profil Zat Aktif Berkhasiat}

Zat aktif berkhasiat dalam ekstrak kulit buah manggis ditentukan profilnya secara kromatografi lapis tipis. Larutan uji yang digunakan adalah isolat alfa mangosteen yang diperoleh dari maserasi kulit buah manggis sebanyak $260 \mathrm{~g}$ dengan 1 liter heksana. Hasil maserasi Hasil maserasi selanjutnya dilarutkan dalam metanol hangat dan aquades dengan perbandingan 20:1\%v/v. Fase metanol, selanjutnya diuapkan kemudian dilarutkan dalam 
campuran heksana dan etil asetat (8:2\%v/v). Hasil larutan tersebut kemudian diuapkan hingga terbentuk serbuk kristal kering. Kristal kering kemudian dilarutkan dalam etanol dan ditotolkan. Larutan uji ekstrak kering kulit buah manggis dibuat dengan menimbang ekstrak sebanyak 0,83 $\mathrm{g}$ dilarutkan dalam $5 \mathrm{ml}$ etanol dan ditotolkan sebanyak $10 \mu \mathrm{l}$. Kondisi penentuan profil zat aktif berkhasiat ekstrak kering kulit buah manggis dapat dilihat pada Tabel 1 .

TABEL 1. Kondisi Penentuan Profil Zat Aktif Berkhasiat Kuersetin secara Kromatografi Lapis Tipis (DepKes RI, 2010).

\begin{tabular}{ll}
\hline \multicolumn{1}{c}{ Parameter } & \multicolumn{1}{c}{ Ketentuan } \\
\hline Fase gerak & Kloroform : etil asetat (9:1) v/v \\
Fase diam & Silika gel 6o F F $_{254}$ \\
Larutan uji & $5 \%$ dalam etanol \\
Volume penotolan & $5-10 \mu$ larutan uji \\
Pengamatan & Sinar UV 254 nm \\
Nilai Rf & O,53 tanpa penampak noda pada sinar \\
& UV 254 nm \\
Warna noda & Hijau kebiruan \\
\hline
\end{tabular}

\section{Optimasi Formula}

Optimasi yang dilakukan pada penelitian ini menggunakan metode factorial design dengan 2 faktor yaitu konsentrasi asam stearat yang mengacu pada konsentrasi lazim pemakaian asam stearat sebagai emulgator untuk sediaan topikal tidak lebih dari 20\% (Rowe, Sheskey and Quinn, 2009), sehingga rentang konsentrasi yang digunakan adalah 10-16\%, maka level tinggi (+1) adalah $16 \%$ dan level rendah $(-1)$ adalah $10 \%$. Sedangkan pada penggunaan trietanolamin sebagai emulgator digunakan konsentrasi dengan rentang 0,1-0,5\%. Sebagai level tinggi (+) adalah $0,5 \%$ dan level rendah (-) $0,1 \%$. Jumlah penelitian $2^{2}=4$ terdiri dari formula (A), (B), (C), dan (D). Dapat dilihat pada Tabel 2.

TABEL 2. Komposisi emulgator dalam formula sediaan krim pelembab ekstrak kering kulit buah manggis

\begin{tabular}{cccccc}
\hline \multirow{2}{*}{ Formula } & \multicolumn{2}{c}{ Nilai Riil (\%) } & \multicolumn{3}{c}{$\begin{array}{c}\text { Nilai Notasi } \\
\text { (x) }\end{array}$} \\
\cline { 2 - 6 } & $\begin{array}{c}\text { Asam } \\
\text { stearat }\end{array}$ & Trietanolamin & X1 & X2 & X12 \\
\hline A & 10 & 0,1 & -1 & -1 & +1 \\
B & 16 & 0,1 & 1 & -1 & -1 \\
C & 10 & 0,5 & -1 & 1 & -1 \\
D & 16 & 0,5 & 1 & 1 & +1 \\
\hline
\end{tabular}

Formula sediaan krim pelembab ekstrak kering kulit buah manggis terdiri dari ekstrak kering kulit buah manggis, asam stearat, trietanolamin, gliseril monostearat, gliserin, propilen glikol, carbomer, metil paraben serta akuades. Dapat dilihat pada Tabel 3 .

\section{Evaluasi Sediaan}

Evaluasi sediaan pelembab terdiri dari evaluasi mutu fisik, evaluasi efektivitas, dan evaluasi keamanan. Evaluasi mutu fisik meliputi organoleptis, pengujian homogenitas, pengujian tipe emulsi (Panda, 2000), pengujian $\mathrm{pH}$ (Tranggono dan Latifah, 2007), pengujian viskositas (Buhse, 2003), pengujian daya sebar
(Garg et al., 2002), daya lekat (Ikhsanudin, 2012), daya tercucikan air (Arnd and Hsu, 2007), Evaluasi efektivitas untuk mengetahui kualitas pelembab dilakukan secara in vitro dengan metode Sorption Desorption Test (SDT). Pengujian dilakukan untuk melihat kemampuan sediaan dalam melembabkan kulit. Hasil uji efektivitas sediaan pelembab diketahui dengan melihat nilai $[\mathrm{AUC}]_{\text {total. yang dihitung berdasarkan }}$ parameter selisih bobot yang diperoleh. Evaluasi keamanan melakukan uji iritasi yang dilakukan menggunakan punggung tangan panelis.

TABEL 3. Formula Sediaan Ekstrak Kulit Buah Manggis.

\begin{tabular}{lccccc}
\hline \multirow{2}{*}{$\begin{array}{c}\text { Formula } \\
\text { hasil } \\
\text { modifikasi }\end{array}$} & $\begin{array}{c}\text { Konsentrasi } \\
\text { acuan (\%) }\end{array}$ & \multicolumn{4}{c}{$\begin{array}{c}\text { Konsentrasi hasil } \\
\text { modifikasi (\%) }\end{array}$} \\
\cline { 3 - 7 } & & FA & FB & FC & FD \\
\hline $\begin{array}{l}\text { Ekstrak kulit } \\
\text { buah manggis }\end{array}$ & 5 & 10 & 10 & 10 & 10 \\
Asam stearat & 12 & 10 & 16 & 10 & 16 \\
$\begin{array}{l}\text { Gliserin } \\
\text { Propilen }\end{array}$ & 5 & 5 & 5 & 5 & 5 \\
glikol & 3 & 3 & 3 & 3 & 3 \\
Gliseril & 2 & 2 & 2 & 2 & 2 \\
monostearat & & 0,1 & 0,1 & 0,5 & 0,5 \\
Trietanolamin & 0,2 & 0,1 & 0,1 & 0,1 & 0,1 \\
Nipagin & 0,1 & & & & \\
Carbomer- & - & 0,1 & 0,1 & 0,1 & 0.1 \\
940 & & Ad & Ad & Ad & Ad \\
Aquades & Ad 100 & 100 & 100 & 100 & 100 \\
\hline
\end{tabular}

Penentuan profil zat aktif berkhasiat alfamangosteen dilakukan untuk mengetahui keberadaan senyawa aktif pada sediaan pelembab. Penimbangan dilakukan sebanyak 5g sediaan krim pelembab yang dilarutkan dengan etanol sebanyak $10 \mathrm{ml}$. Kondisi penentuan profil zat aktif berkhasiat dapat dilihat pada Tabel 1 .

\section{HASIL DAN PEMBAHASAN}

Hasil standarisasi ekstrak yang dilakukan baik spesifik maupun non spesifik menunjukkan bahwa ekstrak kering kulit buah manggis dapat digunakan sebagai bahan baku pada formulasi sediaan krim pelembab ekstrak kering kulit buah manggis. Hasil standarisasi ekstrak yang dilakukan dapat dilihat pada Tabel 4. Standarisasi non spesifik berhubungan dengan aspek kimia, fisika dan mikrobiologi sehingga tidak terkait dengan aspek farmakologi secara langsung tetapi dapat mempengaruhi keamanan dan stabilitas sediaan yang dihasilkan. Sedangkan pada standarisasi spesifik merupakan aspek yang terkait langsung terhadap aktivitas farmokologi.

Hasil evaluasi sediaan krim pelembab ekstrak kering kulit buah manggis yang terdiri dari mutu fisik dan efektivitas sediaan dapat dilihat pada Tabel 5. Hasil analisa statistic yang dilakukan pada pengujian $\mathrm{pH}$, viskositas, daya sebar, daya lekat, daya tercucikan air serta efektivitas sediaan menunjukkan bahwa kombinasi antara asam stearat dan trietanolamin memiliki pengaruh perbedaan bernakna antar formula. Evaluasi mutu fisik organoleptis 
menunjukkan bahwa sediaan krim pelembab memiliki warna coklat, bau khas ekstrak kulit buah manggis dan bentuk semisolid (krim). Pada pengujian tipe emulsi menggunakan larutan metilen blue sediaan krim memiliki tipe emulsi minyak dalam air (m/a) dan sesuai dengan spesifikasi yang ditetapkan. Pengujian homogenitas menunjukkan sediaan homogen dan sesuai dengan spesifikasi yang ditetapkan.

TABEL 4. Hasil pemeriksaan standarisasi ekstrak kering kulit buah manggis (Garcinia mangostana L.)

\begin{tabular}{|c|c|c|}
\hline Jenis Uji & $\begin{array}{c}\text { Hasil } \\
\text { Pengamatan }\end{array}$ & Persyaratan \\
\hline \multicolumn{3}{|l|}{ Organoleptis } \\
\hline Bentuk & Serbuk & Serbuk $(* *)$ \\
\hline - Warna & Coklat & Coklat $(* *)$ \\
\hline - Bau & Khas & Khas $(* *)$ \\
\hline - Rasa & Kelat & Kelat $(* *)$ \\
\hline Pemeriksaan pH & $5,23 \pm 0,05$ & $4,5-5,5\left(^{(* *}\right)$ \\
\hline $\begin{array}{l}\text { Kadar Sari Larut Air } \\
\text { (\%) }\end{array}$ & $96,06 \pm 0,54$ & \\
\hline \multirow{2}{*}{\multicolumn{3}{|c|}{ Etanol (\%) }} \\
\hline & & \\
\hline $\begin{array}{l}\text { Susut Pengeringan } \\
\text { (\%) }\end{array}$ & $3,47 \pm 0,07$ & $3-4,5\left(^{* *}\right)$ \\
\hline Kadar Air (\%) & $4,13 \pm 0,11$ & Maksimal 10\% (*) \\
\hline Kadar Abu Total (\%) & $1,17 \pm 0,02$ & $\begin{array}{l}\text { Tidak lebih dari } \\
2,9 \%\left(^{*}\right)\end{array}$ \\
\hline $\begin{array}{l}\text { Kadar Abu Larut Air } \\
(\%)\end{array}$ & $0,77 \pm 0,05$ & \\
\hline \multicolumn{2}{|l|}{ Larut Asam (\%) } & \\
\hline $\begin{array}{ll}\left({ }^{*}\right) & \text { : Departemen } \\
\left({ }^{* *}\right) & \text { : Certificate }\end{array}$ & esehat & $p$ \\
\hline & & \\
\hline
\end{tabular}

Hasil pengujian efektivitas kelembaban menunjukkan bahwa sediaan krim ekstrak kulit buah manggis mampu menghambat terjadinya penguapan air sehingga dapat dikatakan bahwa sediaan mempunyai efek sebagai pelembab dengan melihat nilai $[\mathrm{AUC}]_{\text {total }}$ yang lebih kecil dibandingkan dengan formula blangko tanpa ekstrak kulit buah manggis.

Hasil pengujian iritasi pada punggung tangan panelis menunjukkan bahwa sediaan krim pelembab ekstrak kering kulit buah manggis tidak mengiritasi kulit yang ditandai dengan tidak munculnya kemerahan, gatal-gatal sampai bengkak pada kulit. Hal ini disebabkan karena bahan yang digunakan tidak toksik dan masih dalam batas rentang lazim pada pemakaiannya.

Hasil penentuan profil zat aktif berkhasiat alfa-mangosteen menunjukkan bahwa isolat alfamangosteen memiliki nilai Rf o,53. Ekstrak kering kulit buah manggis memiliki nilai $\mathrm{Rf} 0,52$ dan sediaan krim pelembab diperoleh nilai $\mathrm{Rf}$ sebanyak 0,52. Perbedaan nilai Rf yang didapatkan mungkin dipengaruhi oleh kejenuhan dari chamber pada saat eluasi, kualitas fase gerak (eluen) yang digunakan. Pada pengamatan menggunakan UV $254 \mathrm{~nm}$ memiliki noda berwarna hijau sedangkan pada UV $366 \mathrm{~nm}$ berwarna kecoklatan (Gambar 2).

Pada pengujian nilai $\mathrm{pH}$, viskositas, daya sebar, daya lekat, daya tercucikan air serta efektivitas sediaan krim pelembab setelah dilakukan analisa statistik dilanjutkan dengan optimasi formula. Optimasi menggunakan metode factorial design dengan program design expert ver 10,0. Hasil Contour plot dari masing-masing respon selanjutnya ditumpang tindihkan (superimposed) untuk melihat daerah optimum dengan respon berupa nilai $\mathrm{pH}$, viskositas, daya sebar, daya lekat, daya tercucikan air serta efektivitas sediaan krim yang diinginkan dapat dilihat pada Gambar 1.
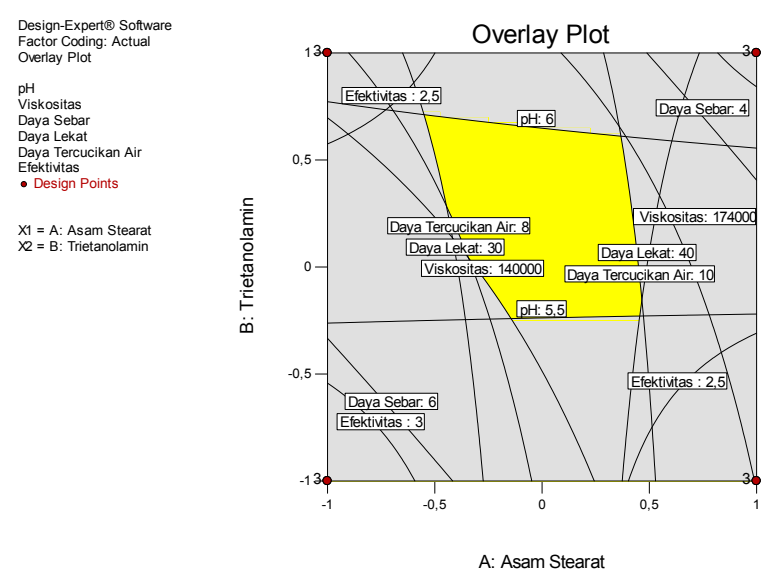

GAMBAR 1. Superimprosed Contour Plot Sediaan Krim Pelembab Ekstrak Kulit Buah Manggis

Hasil analisa berdasarkan desian faktorial pada respon nilai $\mathrm{pH}$ diperoleh persamaan $\mathrm{Y}=5,63+0,007 \mathrm{X}_{\mathrm{A}}+0,56 \mathrm{X}_{\mathrm{B}}+0,081 \mathrm{X}_{\mathrm{A}} \mathrm{X}_{\mathrm{B}}$. Berdasarkan persamaan tersebut diperoleh nilai koefisien faktor $\mathrm{X}_{\mathrm{A}}$ (asam stearat) positif yang berarti pengaruh asam stearat cenderung meningkatkan nilai $\mathrm{pH}$ sediaan. Namun peningkatan yang dihasilkan tidak signifikan, hal ini disebabkan karena sifat asam stearat sendiri yang asam. Demikian pula pada faktor $\mathrm{X}_{\mathrm{B}}$ (trietanolamin) memberikan nilai koefisien yang positif juga sehingga cenderung meningkatkan nilai $\mathrm{pH}$ sediaan. Hal ini disebabkan karena semakin tinggi konsentrasi trietanolamin maka sediaan yang dihasilkan akan semakin basa. Interaksi keduanya (faktor $\mathrm{X}_{\mathrm{A}} \mathrm{X}_{\mathrm{B}}$ ) memberikan nilai kofisien positif yang menunjukkan bahwa kedua komponen tersebut dapat meningkatkan nilai $\mathrm{pH}$ dari sediaan krim pelembab. Hal ini disebabkan karena ketika asam stearat dan trietanolamin saat dicampurkan, sebagian asam stearat dinetralkan dengan trietanolamin yang merupakan bahan alkali sehingga berpengaruh terhadap nilai $\mathrm{pH}$ sediaan (Rowe, Sheskey and Quinn, 2009).

Hasil analisa berdasarkan desian faktorial pada respon nilai viskositas diperoleh persamaan $\mathrm{Y}=1,505 \times 10^{5}+33763,17 \mathrm{X}_{\mathrm{A}}+\quad 21569,50 \mathrm{X}_{\mathrm{B}}-$ $11791,67 \mathrm{X}_{\mathrm{A}} \mathrm{X}_{\mathrm{B}}$. Pada faktor $\mathrm{X}_{\mathrm{A}}$ (asam stearat) memberikan nilai koefisien positif yang berarti pengaruh asam stearat cenderung meningkatkan nilai viskositas sediaan. Hal ini disebabkan karena asam stearat merupakan bahan solid dengan 
fungsi sebagai stiffening agent yang dapat membentuk massa krim, sehingga viskositas sediaan semakin tinggi (Rowe, Sheskey and Quinn, 2009).
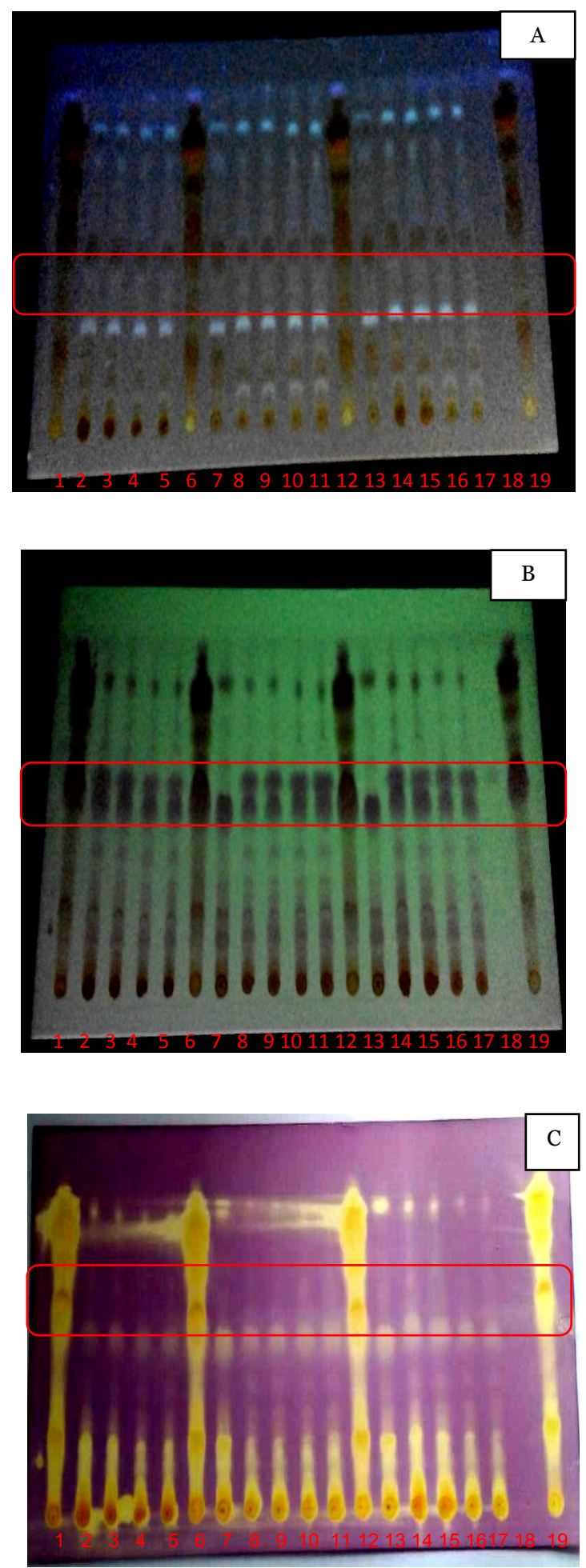

GAMBAR 2. Profil zat aktif berkhasiat (alfa mangosteen) dibawah sinar UV $254 \mathrm{~nm}$ tanpa penampak noda (A), sinar UV $366 \mathrm{~nm}$ (B) dan setelah penyemprotan dengan DPPH (C) Terdapat 19 noda, dimulai dari kiri: pembanding (isolat) (1), formula A (2),(3), formula B (4),(5), isolat (6), ekstrak kering (7), formula C (8),(9), formula D (10),(11), isolat (12), ekstrak kering (13), formula A (14), formula B (15), formula C (16), formula D (17), formula blangko (18), isolat alfa mangosteen (19).
Faktor $\mathrm{X}_{\mathrm{B}}$ (trietanolamin) memiliki nilai koefisien positif sehingga cenderung meningkatkan nilai viskositas sediaan. Hal ini disebabkan karena trietanolamin berfungsi sebagai emulgator fase air, dimana dengan penambahan asam lemak seperti asam stearat akan membentuk emulgator anionik dan meningkatkan ukuran molekul yang halus dan rigid, dimana dengan molekul yang rigid akanmeningkatkan tahanan pada suatu sediaan (Rowe, Sheskey and Quinn, 2009).

Interaksi keduanya (faktor $\mathrm{X}_{\mathrm{A}} \mathrm{X}_{\mathrm{B}}$ ) memberikan nilai kofisien negatif yang menunjukkan bahwa kedua komponen tersebut dapat menurunkan nilai viskositas dari sediaan krim pelembab karena pada konsentrasi rendah asam stearat dan trietanolamin memiliki viskositas paling rendah karena jumlah sisa air yang digunakan semakin besar sehingga memiliki viskositas yang cenderung rendah. Asam stearat merupakan asam lemak tinggi, dimana penggunaannya pada sediaan topikal krim konsistensinya ditentukan dengan jumlah bahan alkali (trietanolamin) yang digunakan.

Hasil analisa berdasarkan desian faktorial pada respon nilai daya sebar diperoleh persamaan $\mathrm{Y}=5,01-0,76 \mathrm{X}_{\mathrm{A}}-0.66 \mathrm{X}_{\mathrm{B}}+0,042 \mathrm{X}_{\mathrm{A}} \mathrm{X}_{\mathrm{B}}$. Pada faktor $\mathrm{X}_{\mathrm{A}}$ (asam stearat) memberikan nilai koefisien negatif yang berarti cenderung menurunkan daya sebar sediaan, hal ini disebabkan karena sediaan yang mengandung konsentrasi asam stearat yang tinggi memiliki konsistensi yang cenderung memadat sehingga nilai daya sebar semakin kecil. Faktor $\mathrm{X}_{\mathrm{B}}$ (trietanolamin) memiliki nilai koefisien negatif sehingga cenderung menurunkan daya sebar sediaan. Hal ini disebabkan karena pada penggunaan konsentrasi tinggi trietanolamin dan asam stearat membentuk sediaan krim yang memiliki konsistensi kental sehingga daya sebar semakin kecil. Secara teori daya sebar sediaan berbanding terbalik dengan viskositas sediaan. Semakin tinggi viskositas sediaan maka kemampuan sediaan untuk menyebar semakin kecil, begitu sebaliknya semakin rendah viskositas sediaan maka diameter penyebaran sediaan semakin besar. Interaksi keduanya $\left(\mathrm{X}_{\mathrm{AB}}\right)$ memberikan nilai kofisien positif yang menunjukkan bahwa kedua komponen tersebut dapat meningkatkan daya sebar dari sediaan krim pelembab. Hal ini disebabkan karena kombinasi emulgator asam stearat dan trietanolamin berpengaruh terhadap konsistensi sediaan. Semakin tinggi konsistensi sediaan, maka daya sebar sediaan semakin kecil dan semakin rendah konsistensi sediaan maka daya sebar sediaan semakin besar (Englina, 2013).

Hasil analisa berdasarkan desian faktorial pada respon nilai daya lekat diperoleh persamaan persamaan $\mathrm{Y}=34,47+11,33 \mathrm{X}_{\mathrm{A}}+0,23 \mathrm{X}_{\mathrm{B}}-4,10 \mathrm{X}_{\mathrm{A}} \mathrm{X}_{\mathrm{B}}$. Pada faktor $\mathrm{X}_{\mathrm{A}}$ (asam stearat) memberikan nilai koefisien positif yang berarti cenderung meningkatkan daya lekat sediaan. Hal ini disebabkan karena asam stearat memiliki fungsi sebagai stiffening agent dimana akan membentuk 
konsistensi yang cenderung memadat dan berpengaruh terhadap vikositas yang tinggi sehingga daya lekat yang didapatkan juga semakin tinggi. Faktor $\mathrm{X}_{\mathrm{B}}$ (trietanolamin) memiliki nilai koefisien positif sehingga cenderung meningkatkan daya lekat sediaan. Hal ini disebabkan karena pada konsentrasi tinggi trietanolamin akan menurunkan viskositas sediaan sehingga daya lekat yang dihasilkan semakin rendah. Sedangkan pada konsentrasi tinggi asam stearat akan menghasilkan sediaan krim yang memiliki viskositas tinggi sehingga daya lekat yang dihasilkan semakin tinggi.

TABEL 5. Hasil Evaluasi Sediaan Krim Pelembab Ekstrak Kulit Buah Manggiis (Garcinia mangostana L.)

\begin{tabular}{|c|c|c|c|c|}
\hline Parameter & FA & FB & F C & FD \\
\hline & & Mutu Fisik & & \\
\hline \multicolumn{5}{|l|}{ Organoleptis } \\
\hline - Bentuk & Krim & Krim & Krim & Krim \\
\hline - Warna & Coklat muda & Coklat muda & Coklat muda & Coklat muda \\
\hline - Bau & Khas & Khas & Khas & Khas \\
\hline pH Sediaan & $5,14 \pm 0,05$ & $4,99 \pm 0,068$ & $6,11 \pm 0,01$ & $6,29 \pm 0,06$ \\
\hline Tipe Emulsi & $\begin{array}{l}\text { Minyak dalam } \\
\text { air }\end{array}$ & $\begin{array}{l}\text { Minyak dalam } \\
\text { air }\end{array}$ & $\begin{array}{l}\text { Minyak dalam } \\
\text { air }\end{array}$ & $\begin{array}{l}\text { Minyak dalam } \\
\text { air }\end{array}$ \\
\hline Viskositas (cps) & $\begin{array}{c}83388 \pm \\
283,17\end{array}$ & $174444 \pm 769,61$ & $\begin{array}{c}150000 \pm \\
1000,00\end{array}$ & $\begin{array}{c}194000 \pm \\
1000,00\end{array}$ \\
\hline \multicolumn{5}{|l|}{$\begin{array}{l}\text { Daya Sebar } \\
(\mathrm{d}=\mathrm{cm})\end{array}$} \\
\hline • $10 \mathrm{~g}$ & $5,78 \pm 0,03$ & $4,11 \pm 0,033$ & $4,2 \pm 0,00$ & $2,97 \pm 0,04$ \\
\hline - $20 g$ & $5,9 \pm 0,00$ & $4,32 \pm 0,04$ & $4,5 \pm 0,01$ & $3,1 \pm 0,01$ \\
\hline - $50 \mathrm{~g}$ & $6,1 \pm 0,01$ & $4,58 \pm 0,07$ & $4,7 \pm 0,05$ & $3,33 \pm 0,05$ \\
\hline $\begin{array}{l}505 \\
\cdot 100 g\end{array}$ & $6,5 \pm 0,06$ & $4,9 \pm 0,06$ & $5,1 \pm 0,06$ & $3,6 \pm 0,06$ \\
\hline Daya Lekat (s) & $18,8 \pm 0,17$ & $49,7 \pm 0,57$ & $27,4 \pm 0,40$ & $41,2 \pm 0,13$ \\
\hline Homogenitas & Homogen & Homogen & Homogen & Homogen \\
\hline Daya Tercucikan air & $4,6 \pm 0,10$ & $\begin{array}{l}11,6 \pm 0,05 \\
\text { Keamanan }\end{array}$ & $7,8 \pm 0,05$ & $11,2 \pm 0,01$ \\
\hline \multirow[t]{2}{*}{ Iritasi } & $\begin{array}{c}\text { Tidak } \\
\text { mengiritasi }\end{array}$ & Tidak mengiritasi & $\begin{array}{c}\text { Tidak } \\
\text { mengiritasi }\end{array}$ & Tidak mengiritasi \\
\hline & & Efektivitas & & \\
\hline Sorption Desorption & & & & \\
\hline Test (SDT) (mg/4jam) & $3,20 \pm 0,01$ & $2,19 \pm 0,09$ & $2,31 \pm 0,03$ & $3,07 \pm 0,04$ \\
\hline
\end{tabular}

Secara teori nilai daya lekat berbanding lurus dengan viskositas sediaan yang dihasilkan (Ikhsanudin, 2012; Fitriana, 2015). Interaksi keduanya (faktor $\mathrm{X}_{\mathrm{AB}}$ ) memberikan nilai kofisien negatif yang menunjukkan bahwa kedua komponen tersebut dapat menurunkan daya lekat dari sediaan krim pelembab. Hal ini disebabkan karena pada konsentrasi rendah trietanolamin dan asam stearat menghasikan viskoitas yang rendah sehingga daya lekat yang dihasilkan rendah. Sedangkan pada viskositas yang tinggi memiliki daya lekat yang tinggi. Namun pada konsentrasi rendah asam stearat dan konsentrasi tinggi trietanolamin memiliki nilai daya lekat yang paling tinggi. Hal ini mungkin disebabkan karena proses pengadukan yang kurang homogen pada saat pengambilan krim untuk pengujian daya lekat sediaan sehingga hasil yang diperoleh tidak sesuai.

Hasil analisa berdasarkan desian faktorial pada respon nilai daya tercucikan air diperoleh persamaan $\mathrm{Y}=8,84+2,58 \mathrm{X}_{\mathrm{A}}+0,67 \mathrm{X}_{\mathrm{B}}-0,89 \quad \mathrm{X}_{\mathrm{A}} \mathrm{X}_{\mathrm{B}}$. Pada faktor $\mathrm{X}_{\mathrm{A}}$ (asam stearat) memberikan nilai koefisien positif yang berarti cenderung meningkatkan respon tercucikan air. Faktor asam stearat berpengaruh asam stearat merupakan emulgator fase minyak sehingga semakin besar konsentrasi asam stearat yang digunakan sediaan yang dihasilkan memiliki viskositas yang tinggi dan volume air yang dibutuhkan untuk dapat tercucikan semakin besar. Semakin besar volume air yang dibutuhkan maka daya tercucikan air kecil. Faktor $\mathrm{X}_{\mathrm{B}}$ (trietanolamin) memiliki nilai koefisien positif sehingga cenderung meningkatkan respon tercucikan air. Namun faktor trietanolamin berpengaruh lebih kecil dibandingkan dengan asam stearat. Hal ini disebabkan trietanolamin merupakan emulgator fase air, semakin tinggi konsentrasi trietanolamin yang digunakan sediaan yang dihasilkan memiliki viskositas kecil dan volume air yang digunakan untuk dapat tercucikan air kecil. Interaksi keduanya (faktor $\mathrm{X}_{\mathrm{AB}}$ ) memberikan nilai kofisien negatif yang menunjukkan bahwa kedua komponen tersebut menurunkan volume tercucikan air dari sediaan krim pelembab. Hal ini disebabkan karena kombinasi emulgator asam stearat dan trietanolamin akan membentuk surfaktan yang bersifat anionik, dimana surfaktan anionik ketika dilarutkan dalam air, basis 
hidrofilik akan membentuk anion sehngga volume air yang dibutuhkan untuk dapat tercucikan semakin kecil (Mitsui, 1997). Interaksi respon nilai daya tercucikan air kombinasi emulgator asam stearat

Hasil analisa berdasarkan desian faktorial pada respon nilai efektivitas diperoleh persamaan $\mathrm{Y}=2,70-0,062 \mathrm{X}_{\mathrm{A}}-\left(6,442 \times 10^{-3}\right) \mathrm{X}_{\mathrm{B}}+\quad 0,44 \mathrm{X}_{\mathrm{A}} \mathrm{X}_{\mathrm{B}}$ Pada faktor $\mathrm{X}_{\mathrm{A}}$ (asam stearat) memberikan nilai koefisien positif yang berarti cenderung menurunkan respon efektivitas sediaan. Asam stearat merupakan asam lemak yang akan membentuk lapisan tipis untuk mencegah terjadinya penguapan air. Trietanolamin menurunkan nilai $[\mathrm{AUC}]_{\text {total }}$ Faktor $\mathrm{X}_{\mathrm{B}}$ (trietanolamin) memiliki nilai koefisien negatif

\section{KESIMPULAN}

Berdasarkan hasil penelitian, formulasi sediaan krim pelembab esktrak kering kulit buah manggis (Garcinia magostana L.) dengan kombinasi penggunaan emulgator asam stearat dan trietanolamin memiliki pengaruh terhadap $\mathrm{pH}$, viskositas, daya sebar, daya lekat, daya tercucikan air dan efektivitas sediaan. Asam stearat sebagai emulgator menurunkan respon terhadap daya sebar dan efektivitas sediaan serta peningkatan terhadap nilai $\mathrm{pH}$, viskositas, daya lekat, daya tercucikan air. Sedangkan trietanolamin yang juga berfungsi sebagai emulgator memberikan respon terhadap penurunan daya sebar dan efektivitas serta peningkatan terhadap $\mathrm{pH}$, viskositas, daya lekat, daya tercucikan air. Interaksi keduanya dapat

\section{DAFTAR PUSTAKA}

Anwar, E., 2012, Eksipien dalam sediaan farmasi (Karakteristik dan aplikasi), Dian rakyat, Jakarta.

Arndt, K.A. and Hsu, J.T.S., 2007, Manual of dermatologic Therapeutics, Lippincott Williams \& Wilkins, Philadelphia, USA.

Buhse, L., 2003. Presented at the Advisory Committe for Pharmaceutical Science Meeting on March 12, 2003.

Departemen Kesehatan RI, 2010. Farmakope Herbal Indonesia, Jakarta: Departemen Kesehatan Republik Indonesia.

Ditjen POM RI, 200o, Parameter Standarisasi Umum Ekstrak Tumbuhan Obat edisi I, Direktorat Jenderal Pengawasan Obat dan Makanan, Direktorat Pengawasan Obat Tradisional, Jakarta.

Englina, Ng., 2013. Optimasi krim sarang burung walet putih (Aerodramus Fuciphagus) tipe m/a dengan variasi emulgator sebagai pencerah kulit menggunakan simplex lattice design, Skripsi. Sarjana Farmasi, Universitas Tanjungpura, Pontianak

Fitriana, R.A., 2015, Optimasi Formula Krim Antibakteri Ekstrak Kulit Buah Manggis (Garcinia mangostana L.) menggunakan Asam Stearat dan Trietanolamin sebagai Alkaizing Agent dengan Metode Desain Faktorial, Skripsi. Fakultas Faramsi Universitaas Muhamadiyah Surakarta, Surakarta. sehingga trietanolamin berpengaruh paling besar pada penurunan respon efektivitas. Hal ini disebabkan karena trietanolamin bersifat higroskopis sehingga memperkecil terjadinya penguapan pada sediaan krim pelembab. Interaksi keduanya (faktor $\mathrm{X}_{\mathrm{AB}}$ ) memberikan nilai kofisien positif yang menunjukkan bahwa kedua komponen tersebut meningkatkan nilai [AUC] $]_{\text {total }}$ dari sediaan krim pelembab. Hal ini disebabkan karena pada konsentrasi rendah asam stearat dan trietanolamin memiliki nilai $[\mathrm{AUC}]_{\text {total }}$ yang paling tinggi dan sediaan yang dihasilkan memiliki viskositas rendah yang mengandung banyak air sehingga penguapan yang terjadi pada sediaan semakin besar.

meningkatkan $\mathrm{pH}$, viskositas, dan efektivitas sediaan serta meningkatkan daya sebar, daya lekat, dan daya tercucikan air pada sediaan pelembab krim ekstrak kulit buah manggis.

Formula optimum sediaan krim pelembab ekstrak kering kulit buah manggis (Garcinia mangostana L.) dapat diperoleh menggunakan konsentrasi kombinasi asam stearat 14,02\% dan konsentrasi trietanolamin sebesar $0,41 \%$ dengan perkiraan memiliki mutu fisik dan efektivitas memenuhi spesifikasi yang diinginkan yaitu nilai pH 5,97, viskositas 171795 cps, daya sebar 4,4 $\mathrm{cm}$, daya lekat 37,65 detik, daya tercucikan air $9,92 \mathrm{ml}$ serta memiliki nilai efektivitas 2,76 $\mathrm{mg} / 4 \mathrm{jam}$.
Garg, A., Aggarwal, D., Garg, S, and Sigla, A.K., 2002. Spreading of semisolid formulation: An Update, Pharmaceutical Technology.

Ikhsanudin, A., 2012. Formulasi vanishing cream minyak atsiri rimpang jahe (Zingiber officinale Roxb) dan uji aktivitas repelan terhadap nyamuk Aedes aegypti betina. Jurnal ilmiah kefarmasian.2 (2). 175-186.

Mahabusakaram W, Iriyachitra P, Taylor W., 1987. Chemical constituents of Garcinia mangostana. J. Nat, Prod. 5o. 474478 .

Mishra, A.K. and Chattopadhyay, P., 2010. Formulation and in-vitro evaluation of antioxidant activity of $\mathrm{o} / \mathrm{w}$ sunscreen cream containing herbal oil as dispersed phase. International Journal of Biomedical Reserch, 5, 210-208.

Mitsui, T. 1997. New Cosmetic Science, Elsevier Science B. V., Amsterdam, Netherland.

Nilar, Nguyen L.H.D, Venkatraman G, Sim K.Y., Horrison L.J., 2005.Xanthones and benzophenones from Garcinia griffithii and Garcinia mangostana.Phytochemistry, 66.1718-1723.

Panda, H. 2000. Herbal Cosmetics Handbook, Asia pasific Business Press, Delhi. India

Pillai, S., M. Cornell, C. Oresajo., 2010.Epidermal barrier, in Draelos, Z.D., Cosmetic Dermatology Products and Procedures, Blackwell Publishing Ltd, UK, 3. 
Rawlings, A.V., Canestrari, D.A. Doblowski, B., 2004. Moisturizer technology versus clinical performence.Dermatol Ther. Suppl 1.49-56.

Rowe, R.C., Sheskey, P,J., and Qiunn, M.E., 2009. Handbook of Phamaceutical Excipient, $6^{\text {th }}$.Pharmaceutical Press and American Pharmacists Assosciation, USA.

Thornfeldt, B., and Bourne, J. 2010, Medicinal Plants of the World, Timber Press, Portland.

Tilaar, M., Wong, L.W., Ranti, A.S., Wasitaatmadja, S., Suryaningsih, dan Maily, 2009. The use of mangosteen pericarp for antioxidant and moisturizing agents in cosmetic, Paper presented at meeting of the Society of Cosmetic of Chemists (IFSCC) Conference, Melbourne, Australia.

Tranggono, R.I.S. and Latifah, F., 2007, Buku Pegangan Ilmu Pengetahuan Kosmetika, Gramedia Pustaka Utama, Jakarta.

Wasitaatmadja, S.M.,1997. Penuntun Ilmu Kosmetik Medik. Penerbit UI Press. Jakarta.

Wasitaatmadja, S.M., 2011. Dasar-dasar peremajaan kulit, dalam S.M. Wasitaatmadja, dan S.L. Menaldi (eds). Peremajaan Kulit, Balai penerbit FKUI, Jakarta. 10-22. 